\title{
Presence of the $\mathrm{P}_{2} \mathrm{X}_{7}$ purinergic receptor on immune cells that invade the rat endometrium during oestrus
}

\author{
Rachel Koshi ${ }^{\text {a }}$, Robson Coutinho-Silva ${ }^{\text {b,e }}$, \\ Cynthia Machado Cascabulho ${ }^{\mathrm{d}}$, Andrea Henrique-Pons ${ }^{\mathrm{d}}$, \\ Gillian E. Knight ${ }^{\mathrm{b}}$, Andrzej Loesch ${ }^{\mathrm{c}}$, Geoffrey Burnstock ${ }^{\mathrm{b}, *}$ \\ a Department of Anatomy, Christian Medical College, Vellore 632002, India \\ ${ }^{\mathrm{b}}$ Autonomic Neuroscience Centre, Royal Free and University College Medical School, \\ Rowland Hill Street, London NW3 2PF, UK \\ ${ }^{\mathrm{c}}$ Department of Anatomy and Developmental Biology, Royal Free and University College Medical School, \\ Rowland Hill Street, London NW3 2PF, UK \\ ${ }^{\mathrm{d}}$ Departamento de Ultraestrutura e Biologia Celular, Instituto Oswaldo Cruz-Fiocruz, Rio de Janeiro, Brasil \\ e Instituto de Biofísica Carlos Chagas Filho, Universidade Federal do Rio de Janeiro, Rio de Janeiro, Brazil
}

Received 27 August 2004; received in revised form 19 April 2005; accepted 26 April 2005

\begin{abstract}
Eosinophils, macrophages and other leucocytes invade the uterine endometrium during oestrus and play a role in the tissue remodeling and immune responses that occur prior to implantation of the fertilized ovum. Adenosine 5'-triphosphate (ATP) and its metabolites influence uterine function via ATP receptors. In this study, we investigated the presence and localisation of the $\mathrm{P} 2 \mathrm{X}_{7}$ nucleotide receptor in the cells that infiltrate the uterine endometrium of adult female rats during oestrus at the electron microscope level, using gold-silver pre-embedding immunocytochemical techniques. $\mathrm{P} 2 \mathrm{X}_{7}$ receptor expression was found in the cytoplasm and the cell membrane of eosinophils, macrophages and fibroblasts in the endometrium during oestrus. These results suggest that ATP-mediated responses may be important in uterine preparation and remodeling before implantation and that this may involve several types of cells. In particular, the presence of $\mathrm{P} 2 \mathrm{X}_{7}$ receptors on endometrial stromal cells may indicate their involvement in apoptosis and immune and inflammatory responses.
\end{abstract}

() 2005 Elsevier Ireland Ltd. All rights reserved.

Keywords: Implantation; Oestrus; Purinergic receptor; Signal transducer; Uterus

* Corresponding author. Tel.: +44 207830 2948; fax: +44 2078302949.
E-mail address: g.burnstock@ucl.ac.uk (G. Burnstock).

0165-0378/\$ - see front matter @ 2005 Elsevier Ireland Ltd. All rights reserved.

doi:10.1016/j.jri.2005.04.006 


\section{Introduction}

Implantation of the fertilized ovum within the uterine wall in mammals is ensured by the close integration of fertilisation with events that prepare the uterus to receive the embryo. Under the influence of pituitary and ovarian hormones, cyclic changes occur in the uterus of sexually mature females (Crowley, 1974). In rats, this oestrus cycle occurs every 4-5 days and is divided into proestrous, oestrus, metoestrus and dioestrus. Oestrus is the time of ovulation and lasts for approximately $24 \mathrm{~h}$. During this time, the endometrium thickens and the uterus is prepared for implantation of the fertilised ovum (Zarrow et al., 1964). At the end of oestrus, if pregnancy has not occurred, a large amount of uterine tissue is shed to prepare for the next cycle. Study of mechanisms controlling endometrial growth, remodeling and regression has generated much interest and is relevant to understanding of uterine function.

A prominent event occurring during oestrus is the accumulation of a large number of blood cells (eosinophils, neutrophils, macrophages, lymphocytes and plasma cells) in the endometrium of rats (Lee, 1982; Tassell et al., 2000) and other mammals (Padykula, 1976; McMaster et al., 1992; Wang et al., 2000). These cells release a number of potent regulators and play an important role in uterine growth, remodeling (Luque et al., 1997) and immunity (Wang et al., 2000).

Adenosine $5^{\prime}$-triphosphate (ATP) and its metabolites are extracellular signalling molecules released from several cell types under physiologic and pathophysiologic conditions (Gordon, 1986; Burnstock, 2001) and there is evidence to show that ATP influences uterine functions (Gorodeski and Goldfarb, 1997). The effects of ATP are mediated by interactions of the nucleotide with effector cells through cell surface receptors called P2 purinergic receptors linked to specific signal transduction pathways (Abbracchio and Burnstock, 1998; Ralevic and Burnstock, 1998). These receptors, when activated by purines, perform several important cellular functions. We are particularly interested in the $\mathrm{P}_{2} \mathrm{X}_{7}$ ATP receptor that plays a role in apoptosis, development of immunity and control of microbial infection (Di Virgilio, 1995; Coutinho-Silva et al., 2001; Di Virgilio et al., 2001). The role of $\mathrm{P}_{2} \mathrm{X}_{7}$ receptors on cells of the uterus during oestrus is discussed in relation to the role of the endometrium during embryo implantation. Here, immunofluorescence and electron microscopic immunoytochemical techniques have been applied to examine the presence of $\mathrm{P} 2 \mathrm{X}_{7}$ receptor protein in the endometrium during rat oestrus.

\section{Materials and methods}

\subsection{Animals}

Principles of good laboratory animal care were followed, and animal experimentation was in compliance with specific national laws and regulations of the Home Office (UK) covering Schedule One procedures in accordance with the Animals (Scientific Procedures) Act, 1986. A total of 25 female Sprague-Dawley rats (approximately $250 \mathrm{~g}$ ) were used in the study. Stages of the oestrus cycle were determined by vaginal smear; cycles were established for a minimum of 2 weeks before the animals were used. The rats were killed by 
asphyxiation with $\mathrm{CO}_{2}$ and cervical dislocation and the two uterine horns were removed. Uterine tissue was taken from the uterine horns and processed for immunofluorescence, electron-immunocytochemistry and standard electron microscopy.

\subsection{Electron microscopy}

For standard electron microscopy, uterine tissues were immersion-fixed in $2 \%$ glutaraldehyde in $0.1 \mathrm{M}$ sodium cacodylate buffer ( $\mathrm{pH} 7.4$ ) at $4{ }^{\circ} \mathrm{C}$ for $2 \mathrm{~h}$, washed in stock buffer, post-fixed in $1 \%$ osmium tetroxide (in stock buffer) for $1 \mathrm{~h}$ at $4{ }^{\circ} \mathrm{C}$, washed in $0.1 \mathrm{M}$ sodium acetate buffer ( $\mathrm{pH} 7.4$ ), block stained with $2 \%$ uranyl acetate (in sodium acetate buffer) for $30 \mathrm{~min}$ at $4{ }^{\circ} \mathrm{C}$, dehydrated in graded concentrations of ethanol and embedded in Araldite. Ultrathin sections were cut at $80 \mathrm{~nm}$ thickness, stained with uranyl acetate and lead citrate and examined with a JEM-1010 electron microscope.

\subsection{Immunofluorescence-confocal microscopy}

Fresh uterine tissues from six rats (three non-oestrus controls and three in oestrus) were imbedded in O.C.T. compound (BDH/Merk, Leicester, UK) and fast frozen in precooled (by liquid nitrogen) isopentane. Using a Reichert-Jung CM1800 cryostat, uterine tissues were cross-sectioned (at least five sections per animal) at $12 \mu \mathrm{m}$ and collected on gelatin-coated slides and then fixed for $10 \mathrm{~min}$ in acetone. Sections were then (i) washed in phosphatebuffered saline (PBS), placed for $1 \mathrm{~h}$ in 5\% non-immune normal goat serum (NGS) (Nordic Immunology, Tilburg, The Netherlands), (ii) incubated overnight with a polyclonal antibody to $\mathrm{P}_{2} \mathrm{X}_{7}$ receptors (Roche Palo Alto, CA, USA) at a dilution $3 \mu \mathrm{g} / \mathrm{ml}$ of PBS containing $1 \%$ NGS and $0.1 \%$ sodium azide, (iii) washed in PBS, (iv) incubated for 90 min with Aleza Fluor 568 goat anti-rabbit IgG (H and L) (Leiden, Netherlands) diluted 1:400 in PBS, (v) washed in PBS, and (vi) mounted in Citifluor for examination with a fluorescence confocal microscope (BioRad 2001, Radiance system). Fluorescence filters at $568 \mathrm{~nm}$ excitation line, and objective lenses with $10 \times$ and $20 \times$ or $40 \times$ (oil immersion), were used for examination of the specimens. Consecutive individual images were collected at $2 \mu \mathrm{m}$ intervals and stored digitally. Sections were also examined using a Zeiss Axioplan microscope (Zeiss, Germany) with a Leica DC200 digital camera.

\subsection{Electron-immunocytochemistry}

Uterine tissues from six rats (three controls and three in oestrus) were immersion-fixed at $4{ }^{\circ} \mathrm{C}$ for $2 \mathrm{~h}$ in $4 \%$ paraformaldehyde and $0.2 \%$ glutaraldehyde in $0.1 \mathrm{M}$ phosphate buffer (pH 7.4), washed in $0.05 \mathrm{M}$ Tris-buffered saline (TBS) at pH 7.6, embedded in albumin and sectioned at 50-70 $\mu \mathrm{m}$ thickness on a vibratome. To detect $\mathrm{P} 2 \mathrm{X}_{7}$ receptor protein, sections were processed for the pre-embedding immunogold-silver labeling technique (see Loesch and Burnstock, 2001) using a polyclonal anti $\mathrm{P}_{2} \mathrm{X}_{7}$ receptor antibody (Roche Palo Alto). After blocking non-specific protein binding sites with $10 \%$ non-immune NGS, the sections were incubated for $24-30 \mathrm{~h}$ at room temperature with the $\mathrm{P}_{2} \mathrm{X}_{7}$ antibody (at a dilution $3 \mathrm{ug} / 1 \mathrm{ml}$ TBS containing $0.1 \%$ sodium azide and $1 \%$ NGS). Sections were then washed in TBS, incubated for $18-24 \mathrm{~h}$ with a $1 \mathrm{~nm}$ gold-conjugated goat-antirabbit $\operatorname{IgG}(\mathrm{H}+\mathrm{L})$ serum 
(British Biocell Int., Cardiff, Wales, UK) diluted 1:300 in TBS containing 0.1\% sodium azide and 1\% NGS. After thorough washing in TBS and then $0.1 \mathrm{M}$ phosphate buffer (pH 7.4), sections were fixed for $10 \mathrm{~min}$ in $1 \%$ glutaraldehyde (in phosphate buffer), washed in deionised distilled $\mathrm{H}_{2} \mathrm{O}(10 \times 5 \mathrm{~min})$ and the immunoreaction was enhanced using a silver enhancing kit (British Biocell Int.). Sections were washed in deionised distilled $\mathrm{H}_{2} \mathrm{O}$, postfixed with $1 \%$ osmium tetroxide, dehydrated in a graded series of ethanol followed by propylene oxide and embedded in Araldite. Approximately 12 ultrathin sections were cut from each Araldite-embedded specimen. These were stained with uranyl acetate and lead citrate and examined with a JEM-1010 electron microscope.

\section{5. $P 2 X_{7}$ receptor antibody and immunocytochemical controls}

The polyclonal antibody to $\mathrm{P}_{2} \mathrm{X}_{7}$ was raised in New Zealand rabbits against specific peptide sequence of the $\mathrm{P}_{2} \mathrm{X}_{7}$ receptor subtype and characterised by Roche Palo Alto, as described by Oglesby et al. (1999). This study showed that reabsorption of P2X $X_{7}$ antibody with the homologous antigen (synthetic peptide used for the generation of the antibody) at a concentration of $5 \mu \mathrm{g} / \mathrm{ml}$ of diluted antibody ( $5 \mu \mathrm{g}$ peptide: $3 \mu \mathrm{g}$ antibody) was sufficient to abolish immunostaining. In the present study, the routine controls were applied with omission of the primary and secondary antibody steps, independently. These resulted in lack of immunolabelling.

\subsection{Controls to confirm that leucocyte infiltration is confined to oestrus}

Uterine tissue from non-oestrus controls was obtained (two rats in dioestrus and two in metoestrus) to confirm that there was no leucocyte infiltration into the endometrium during these stages.

\subsection{Isolation of rat spleen and uteri cells}

Eosinophil fractions were isolated based on the modified procedures of Wang et al. (2000) and Robertson et al. (2000). Briefly, spleen and uteri were collected from rats in oestrus. For splenic eosinophils, the spleens were collected and the eosinophils were gently removed by mechanical dissociation and re-suspended in buffered salt solution (BSS) and erythrocytes were lysed by a brief osmotic sock. The uteri were excised, trimmed of mesentery and fat, slit lengthwise, rinsed in PBS, then chopped into fine fragments and incubated in collagenase type 1 ( $1 \mathrm{mg} / \mathrm{ml}$, Sigma Chemical Co., Poole, UK) plus DNAase 1 type II $(25 \mu \mathrm{g} / \mathrm{ml}$, Sigma) in DEMEM medium containing $10 \%$ fetal calf serum (FCS; $2.5 \mathrm{~h}$ at room temperature, with magnetic stirring). Tissue disruption was aided by repeated forceful pipetting at $30 \mathrm{~min}$ intervals during digestion. An equal volume of $5 \mathrm{mM}$ EDTA in Hank's buffered salt solution (HBSS, without $\mathrm{Ca}^{2+}$ and $\mathrm{Mg}^{2+}$ ) was added $20 \mathrm{~min}$ before the end of the incubation. A single cell suspension was recovered by filtering the digestion mixture through a $70 \mu \mathrm{m}$ cell strainer (Falcon, Franklin Lakes, NJ) to remove cells aggregate and tissue debris. After two washes in HBSS containing 5\% FCS, on both preparations of cells (spleen and uteri) macrophages and lymphocytes were removed by centrifugation on a Ficoll density gradient (Amersham Pharmacia Biotech). Cells were further fractionated over a metrizamide gradient to enrich 
the eosinophil population. Metrizamide was made up to 18.5 and $22.5 \%(\mathrm{w} / \mathrm{v})$ solution in HBSS. Two milliliter of the $22.5 \%$ metrizamide solution were overlaid with $2 \mathrm{ml}$ of the $18.5 \%$ solution in a $15 \mathrm{ml}$ centrifuge tube. One milliliter of the $1 \times 10^{7}$ cells $/ \mathrm{ml}$ suspension of non-adherent cells was added and the tube centrifuged for $15 \mathrm{~min}$ at $400 \times \mathrm{g}$. Populations enriched with eosinophils were collected at the 18.5-22.5\% metrizamide interface and kept on ice until use. Uteri from a total of nine rats in oestrus were used.
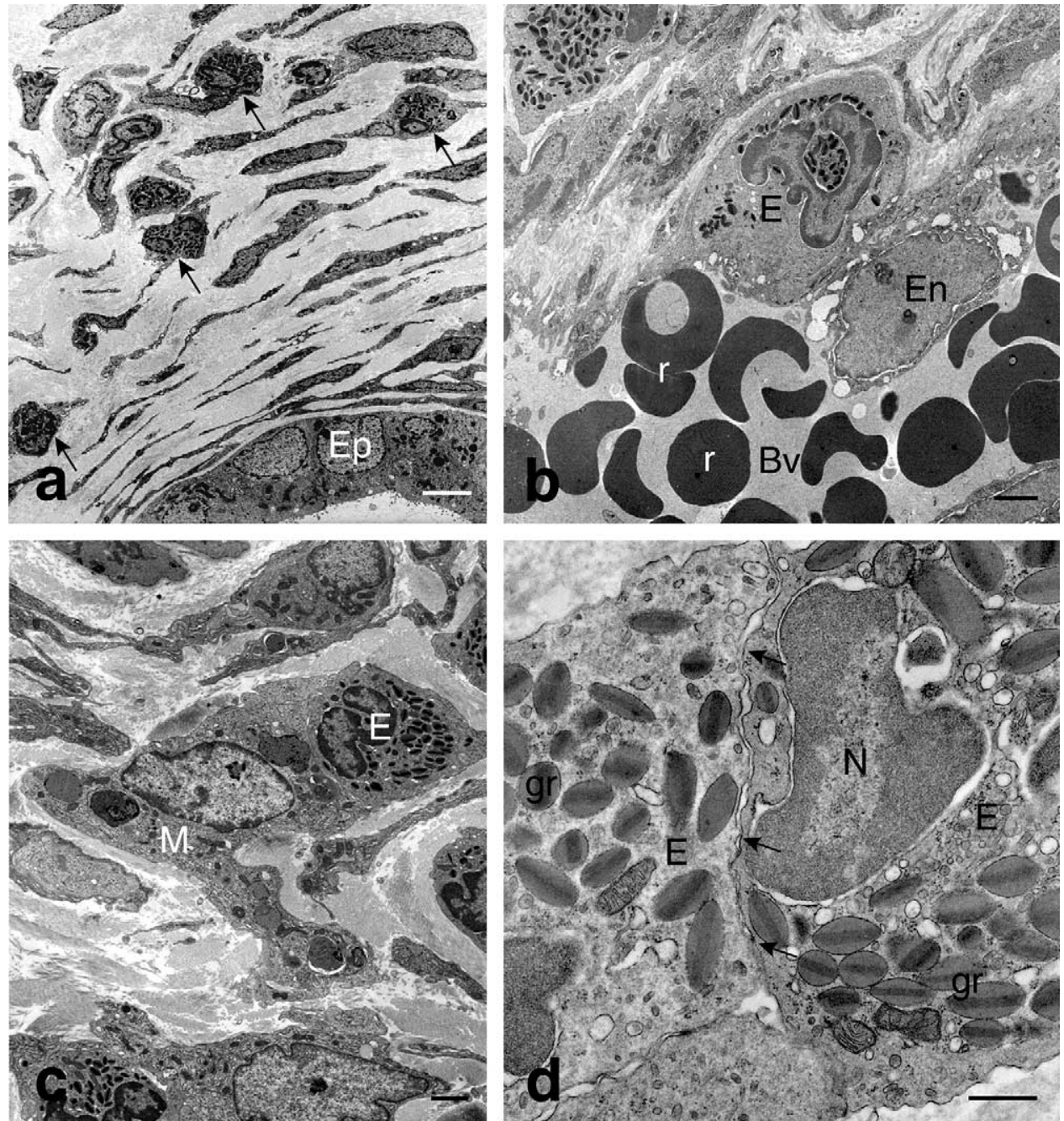

Fig. 1. Standard electron microscopy of uterine tissue during oestrus shows a diverse location of eosinophils. (a) A fragment of endometrial lamina propria showing numerous eosinophils (arrows). Ep-epithelium. (b) An eosinophil (E) associated with an endometrial blood vessel (Bv). En-endothelium; r-red blood cells. (c) Close relationship between an eosinophil (E) and a macrophage (M). (d) Higher magnification of contact between eosinophils (arrows). $\mathrm{N}$-nucleus, gr-granules. $\mathrm{Bar}=5 \mu \mathrm{m}$ (a), $2 \mu \mathrm{m}$ (b and c), $500 \mathrm{~nm}$ (d). 


\subsection{ATPe-induced permeabilization assay}

To assess ATPe-induced membrane permeabilization, the membrane-impermeable DNA-staining fluorescent dye propidium iodide (PI) $2.5 \mu \mathrm{M}$ (Molecular Probes, Eugene) was used. The spleen and uterus cell suspensions were pre-warmed for $5 \mathrm{~min}$ in PBS/bovine serum albumin at $37{ }^{\circ} \mathrm{C}$ and then incubated for $10 \mathrm{~min}$ either in the presence or absence of $5 \mathrm{mM}$ ATP. During the last $5 \mathrm{~min}$ of incubation, the fluorescent dye PI $(2.5 \mu \mathrm{M})$ was added to the cells. Samples of 5000 cells from three animals were acquired and the cells were gated by forward and side scatter for granulocytes, which were immediately analyzed using a FACScalibur (Becton \& Dickinson, San Jose, CA, USA) flow cytometer. All data were analyzed using the WinMDI (Multiple Document Interface Flow Cytometry Application, V2.8) software.

\subsection{7-Amino actinomycin $D(7 A A D)$ staining and flow cytometry}

In order to evaluate spontaneous apoptosis, freshly isolated spleen and uterus eosinophils cells, obtained from a total of nine animals were incubated for $40 \mathrm{~min}$ with $10 \mu \mathrm{g} / \mathrm{ml}$ 7AAD (Sigma) at $4{ }^{\circ} \mathrm{C}$ in the dark. Samples of $10^{4}$ cells stained with 7AAD and gated by forward and side scatter for granulocytes were analysed by FACScalibur (Becton \& Dickinson) flow cytometer. Cells without 7AAD labeling were considered viable, while apoptotic and late-apoptotic/dead cells showed low and high 7AAD staining respectively (Hernandez et al., 2003; Philpott et al., 1996).

7AAD has the advantage over PI and related compounds in that it is able to identify early apoptotic cells (7AAD-dim), which retain membrane integrity separate from
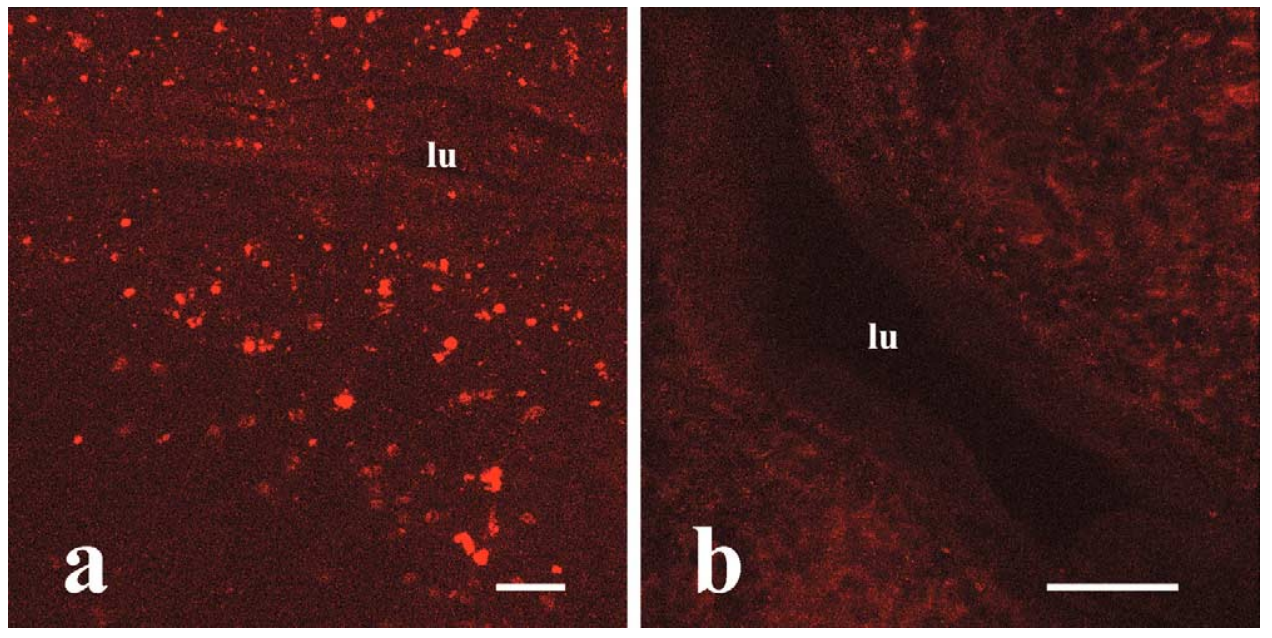

Fig. 2. Immunofluorescence-confocal microscopy of uterine tissue during oestrus. (a) The presence of $\mathrm{P} 2 \mathrm{X}_{7}$ receptor-positive cells (red labelled) in the lamina propria around the narrowed uterine lumen (lu). (b) An example of an immunocytochemical control preparation of uterus during oestrus showing no immunolabelling when anti$\mathrm{P}^{2} \mathrm{X}_{7}$ antibody step was omitted. Lumen, lu. Bar $=50 \mu \mathrm{m}$ (a), $50 \mu \mathrm{m}$ (b). 
late-apoptotic/dead forms (7AAD-high), in which membrane integrity has been lost (Philpott et al., 1996).

\section{Results}

\subsection{Electron microscopy}

Standard electron microscopy confirmed the rich infiltration of eosinophils within the endometrium during oestrus (Fig. 1). These cells were easily recognized by the presence of characteristic cytoplasmic granules. Eosinophils were mostly located in the connective tissue of the lamina propria (Fig. 1a), where fibroblasts and macrophages could also be

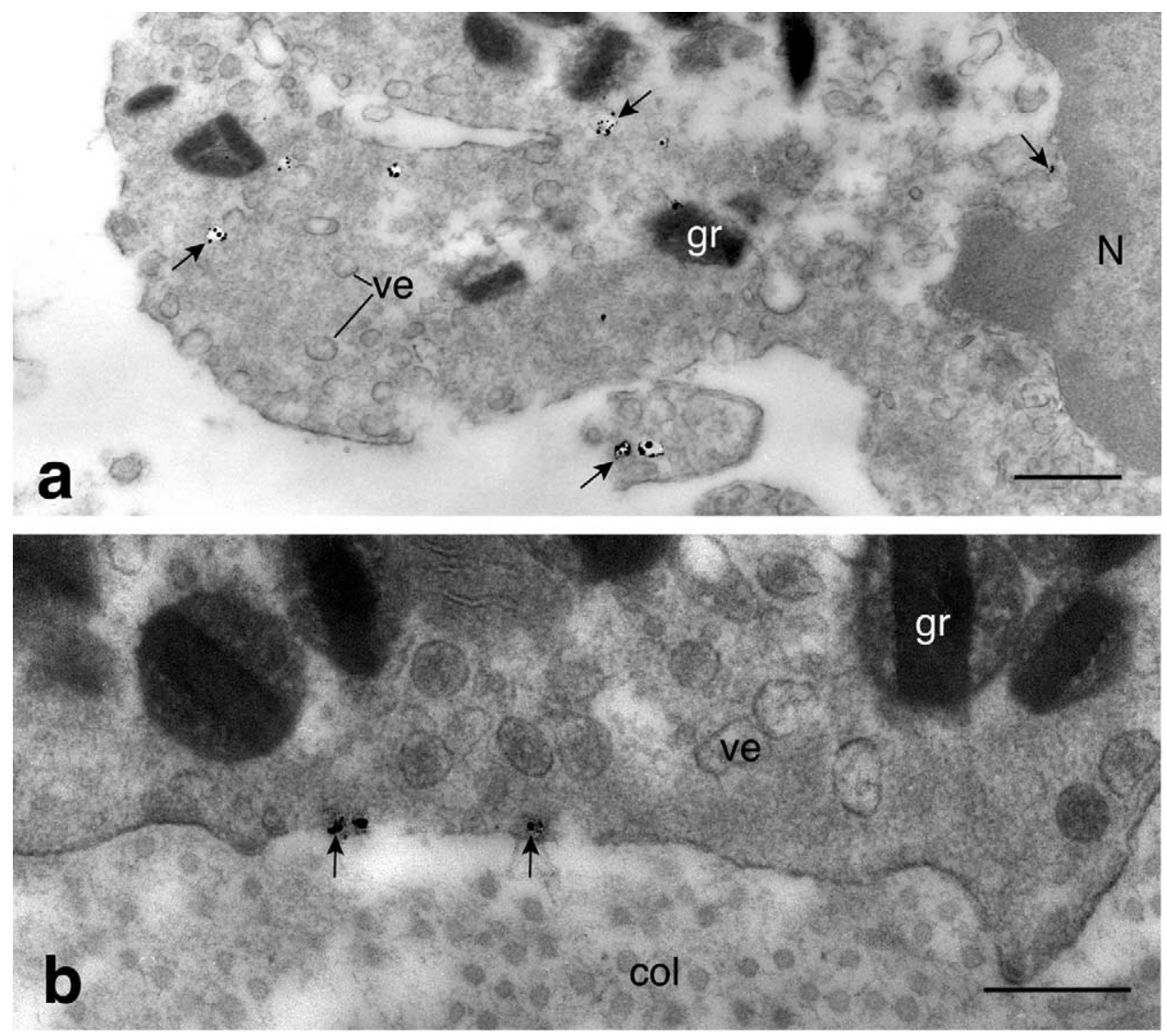

Fig. 3. Electron-immunocytochemistry of eosinophils labelled for $\mathrm{P} 2 \mathrm{X}_{7}$ receptors with immunogold-silver techniques. (a) Labelled eosinophils mostly show cytoplasmic and to some extend vesicle-associated distribution of black gold-silver grains (arrows). N-nucleus, gr-granules, ve-vesicles. (b) Higher magnification of labelled eosinophil displaying gold-silver grains in association with the cell membrane (arrows). ve-vesicle, gr-granules, col—collagen. Bar $=500 \mathrm{~nm}(\mathrm{a}), 200 \mathrm{~nm}(\mathrm{~b})$. 
seen. It was often observed that eosinophils were associated with blood vessels (Fig. 1b) and macrophages (Fig. 1c). In addition, eosinophils were frequently clustered together and exhibited direct cell-to-cell contacts (Fig. 1d). No leucocyte infiltration was seen during dioestrus or metoestrus.

\subsection{Immunofluorescence-confocal microscopy}

$\mathrm{P} 2 \mathrm{X}_{7}$ receptor-positive immunoreactivity was observed in uterine tissues during oestrus (Fig. 2a). The immunoreactivity labelled a number of endometrial stromal cells. The intense
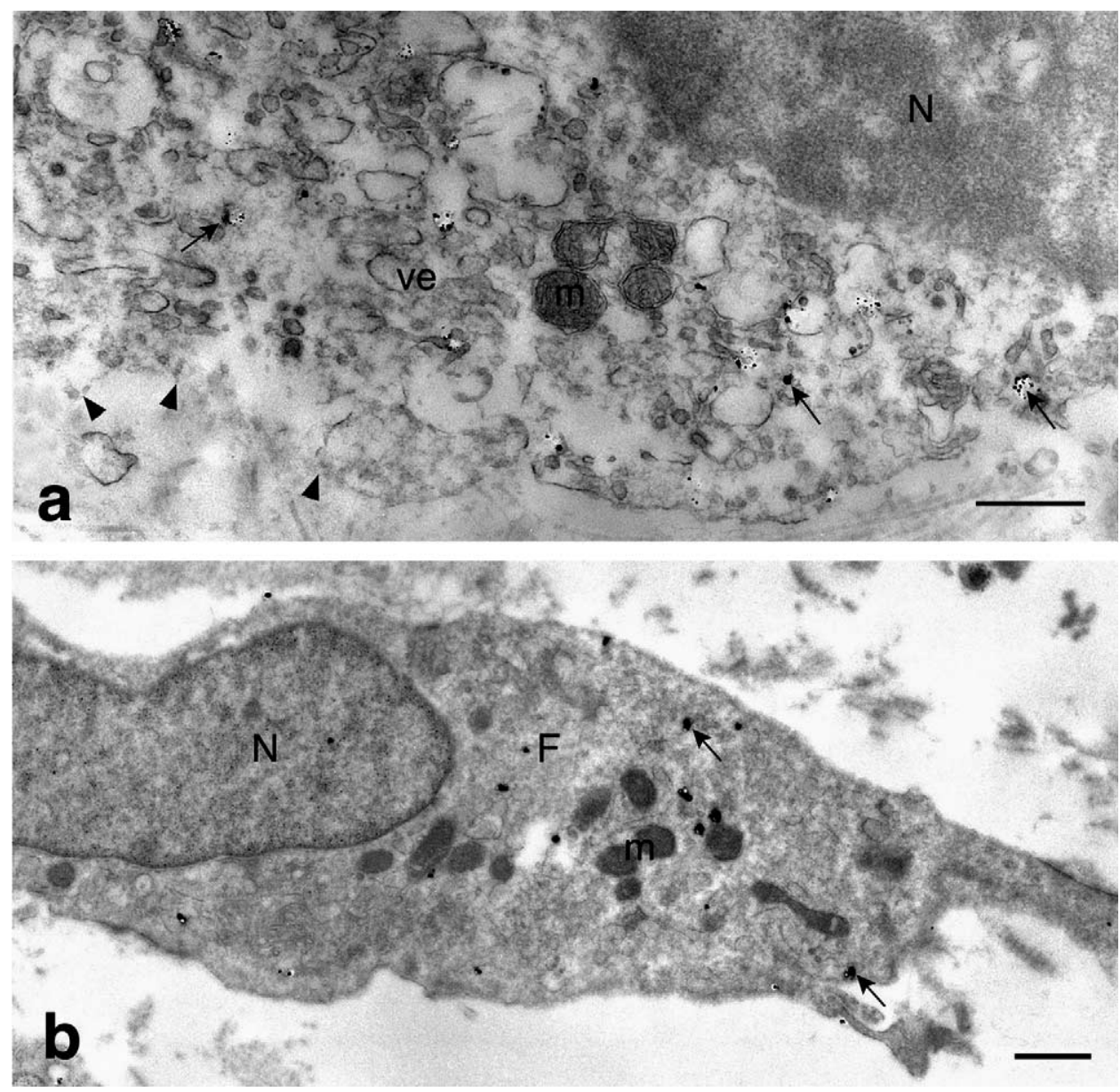

Fig. 4. Electron-immunocytochemistry of (a) macrophage and (b) fibroblast labelled for $\mathrm{P}_{2} \mathrm{X}_{7}$ receptors with immunogold-silver techniques. (a) Macrophage displaying numerous gold-silver grains (arrows) in the cytoplasm; some grains are localised close to cellular organelles or structures including cytoplasmic vesicles. Note partial lysis of the cell membrane in the lower left region (arrowheads) suggesting cell apoptosis. $\mathrm{N}$-nucleus, ve-vesicles, $\mathrm{m}$-mitochondria. (b) Fibroblast (F) displays cytoplasmic location of immunoreactivity for $\mathrm{P} 2 \mathrm{X}_{7}$ receptors (arrows). $\mathrm{N}$-nucleus, $\mathrm{m}$-mitochondria. $\mathrm{Bar}=500 \mathrm{~nm}$ ( $\mathrm{a}$ and $\mathrm{b}$ ). 
labeling was observed in the cells located near the uterine lumen. In contrast, no immunoreactivity was observed in immunocytochemical control preparations of uterine tissue during oestrus (Fig. 2b).

\subsection{Electron-immunocytochemistry}

Immunogold-silver labeling techniques revealed immunoreactivity for $\mathrm{P} 2 \mathrm{X}_{7}$ receptors in the endometrial stromal cells of the rat uterus (Figs. 3 and 4). Labeling was observed in eosinophils (Fig. 3), macrophages and fibroblasts (Fig. 4). Gold-silver grains marking the presence of $\mathrm{P} 2 \mathrm{X}_{7}$ receptor proteins were noted in the cytoplasm, some clearly being vesicleassociated, and in association with the cell membrane, at least in some eosinophils (Fig. 3a

(A) $0.4 \%$

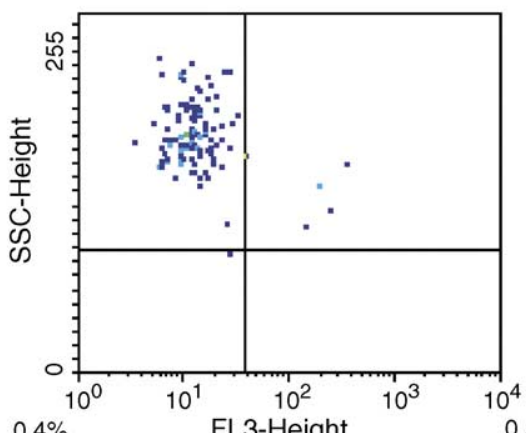

$76.8 \%$

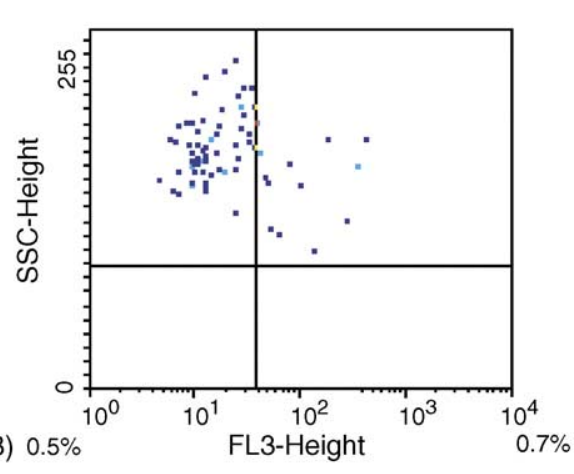

(B) $0.5 \%$

$20.7 \%$

$73.0 \%$

$24.0 \%$
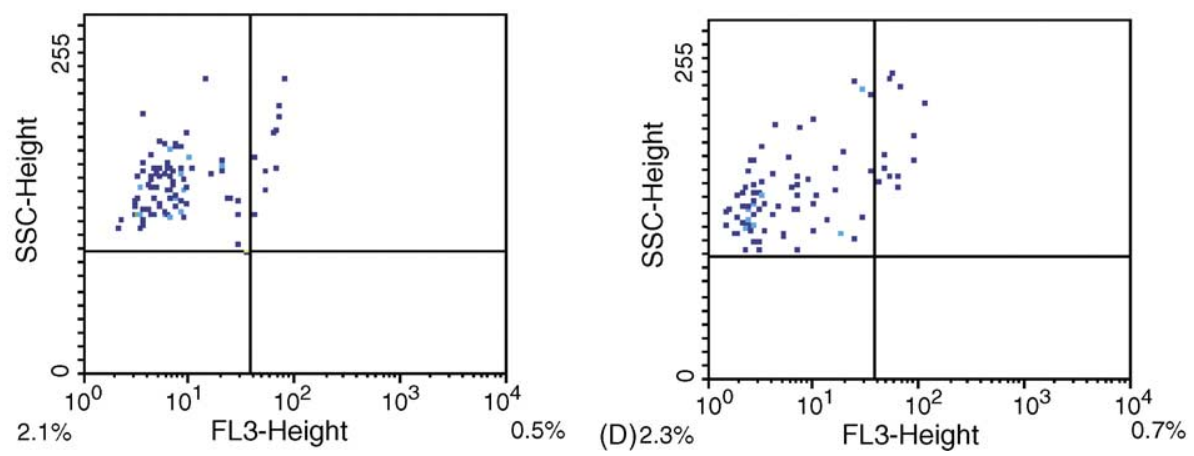

Fig. 5. ATP-induced permeabilization of uterine and spleen cells suspension. Eosinophils enriched cell population from uterus before (A) and after (B) ATP treatment. Eosinophils enriched cell population from spleen before (C) and after (D) ATP treatment. Note that in both cell groups ATP induced cell permeabilization, the effect on uterus cells was much greater than on cells of spleen origin. After isolation of the cells (as described in Section 2) the cells were selected for analysis based on forward and side scatter for granulocytes. Results are from a total of nine animals in oestrus, pooled tissue from three animals, repeated in triplicate. 

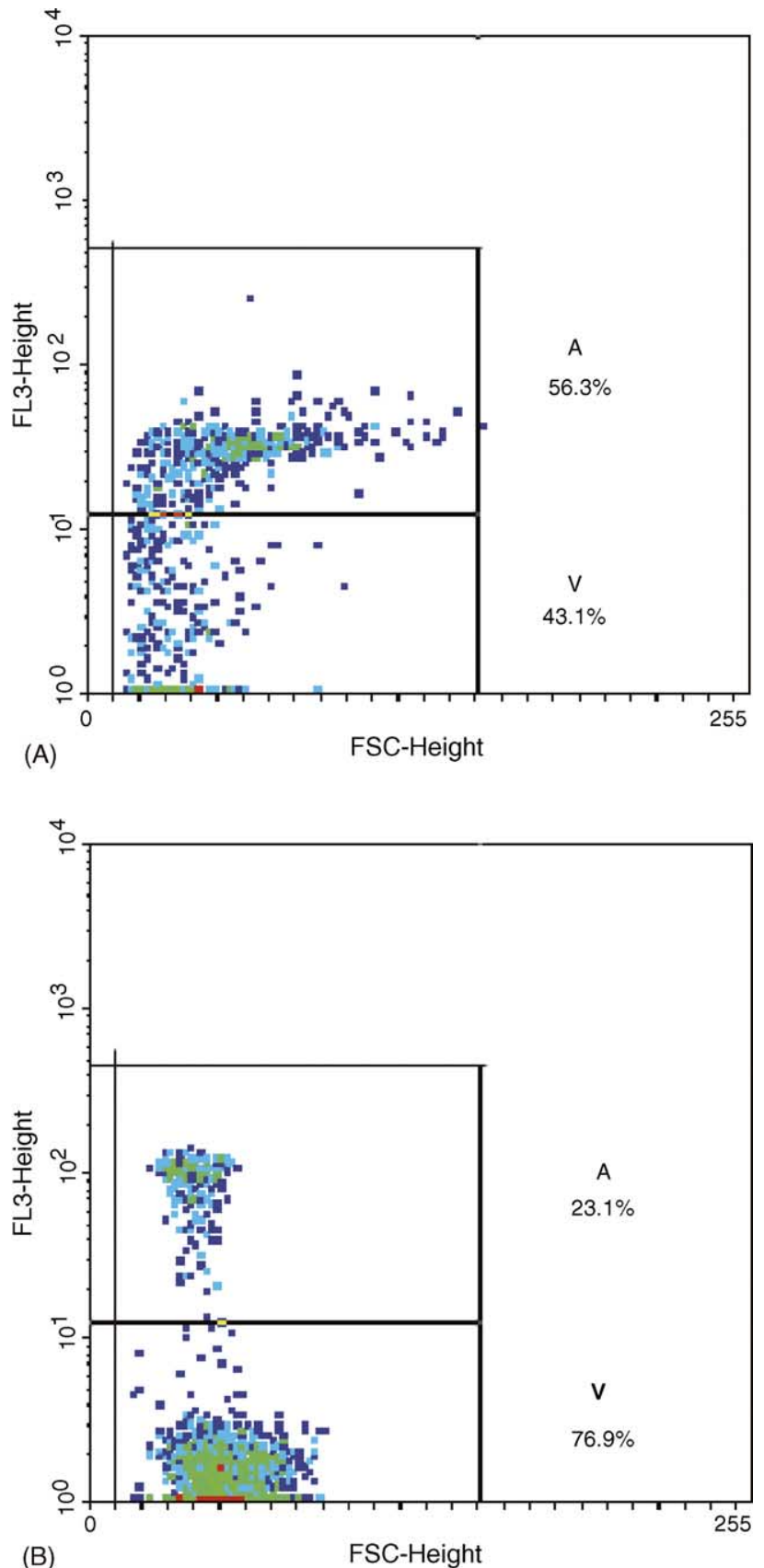

Fig. 6. Scattergrams of 7AAD-stained cells representing apoptotic (low staining) and late-apoptotic/dead (high staining) cells. (A) Cells isolated from uterus; (B) cells isolated from spleen. FSC, forward light scatter; FL3, 7AAD fluorescence; A, apoptotic; V, viable cells. Results are from a total of nine animals in oestrus, pooled tissue from three animals, repeated in triplicate. 
and b). In labelled macrophages, gold-silver grains were mostly seen in the cytoplasm, some being vesicle associated, and to a lesser extent near the cell membrane (Fig. 4a). These cells usually contained numerous vesicles of various sizes and lipofuscin pigment granules. Fig. 4b is an example of the labelled fibroblasts, where gold-silver grains were mostly located in the cytoplasm.

\subsection{ATPe-induced permeabilization on uterine and spleen cells}

One of the main characteristics of functional $\mathrm{P} 2 \mathrm{X}_{7}$ expression in various cells types is the phenomenon of permeabilization. We assessed whether eosinophils from uterus and spleen were able to permeabilize their plasma membranes in the presence of ATP. As can be seen in Fig. 5, cells from both sites were sensitive to ATP but, while 33\% of uterine cells became positively stained for PI after ATP treatment (Fig. 5A and B), only $24 \%$ of spleen cells were positively stained (Fig. 5C and D). If specific staining only is considered, then the difference between uterine and spleen cells is even greater-13 and 3\% for uterine and spleen cells, respectively.

\subsection{Apoptotic eosinophils from uterus and spleen}

Using 7AAD staining to evaluate spontaneous apoptosis, we compared eosinophil staining from uterus and spleen. As shown in Fig. 6, there is more spontaneous apoptosis on cells isolated from uterus (Fig. 6A) than spleen (Fig. 6B). While approximately 56\% of cells isolated from uterus were medium stained with 7AAD, only approximately $23 \%$ of cells isolated from spleen presented this medium staining.

\section{Discussion}

The well-known phenomenon of the rich presence of eosinophils in the rat endometrial stroma during oestrus with formation of eosinophil clusters in intimate cell-to-cell contact as described by Ross and Klebanoff (1966) was confirmed by electron microscopy in the present study. Furthermore, fluorescence microscopic examination showed that stromal cells displayed immunoreactivity for $\mathrm{P} 2 \mathrm{X}_{7}$ receptor protein during oestrus, whilst the application of electron-immunocytochemistry localised the immunoreactivity to eosinophils, macrophages and fibroblasts. These support the observations by Tassell et al. (2000), showing the presence of $\mathrm{P} 2 \mathrm{X}_{7}$ receptor protein in uterine stroma. Immunoreactivity for the $\mathrm{P} 2 \mathrm{X}_{7}$ receptor was primarily associated with the cell cytoplasm, in addition, some regions of the cell membrane and/or membrane-associated vesicles were clearly labelled. Intracellular localisation of the $\mathrm{P}_{2} \mathrm{X}_{7}$ receptor is well documented (Bardini et al., 2000; Lee et al., 2000; Atkinson et al., 2002). This is characteristic of internalization and recycling of activated receptors as a part of the down-regulation process after in vivo stimulation (Dutton et al., 2000; Li et al., 2000; Ennion and Evans, 2001) or possibly due to a general intracellular receptor site for the $\mathrm{P}_{2} \mathrm{X}_{7}$ receptors (Atkinson et al., 2002).

In preparation for receiving the fertilized ovum, many changes occur in the endometrium during oestrus. Endometrial leucocytes regulate these changes by their involvement in 
uterine remodeling (Luque et al., 1997), cytokine secretion and development of immunity (Salamonsen et al., 2000). Our finding of the presence of $\mathrm{P}_{2} \mathrm{X}_{7}$ receptor, a molecule associated with apoptosis, cytokine regulation and immune activities on endometrial leucocytes, suggests that many of the uterine functions regulated by leucocytes may be ATP-mediated.

ATP is known to mediate apoptosis by activation of $\mathrm{P} 2 \mathrm{X}_{7}$ receptors (Di Virgilio, 1995; Coutinho-Silva et al., 1999), and apoptotic epithelial cells of the skin and gut demonstrate strong immunoreactivity for the $\mathrm{P} 2 \mathrm{X}_{7}$ receptor (Gröschel-Stewart et al., 1999a,b). Similarly, apoptotic uterine epithelial cells adjacent to the implanting blastocyst have been found to be $\mathrm{P} 2 \mathrm{X}_{7}$ positive (Tassell et al., 2000) and, during oestrus, uterine epithelial cells express $\mathrm{P} 2 \mathrm{X}_{7}$ receptors (Bardini et al., 2000). In the present study, most of the eosinophils observed at the ultrastructural level did not show obvious morphological features of apoptosis. However, some of the $\mathrm{P} 2 \mathrm{X}_{7}$-positive macrophages displayed partial lysis of the cell membrane consistent with cell death. Also an increased number of apoptotic cells (eosinophils) in uterine stroma during oestrus were revealed using staining with 7AAD. Taken together, these findings support earlier observations by Tassell et al. (2000) suggesting that apoptotic processes take place within the rat uterus.

During early pregnancy, the embryo-fetus with its placental membranes is viewed as a successful allograft (Padykula and Campbell, 1976) and the ability of the uterine endometrium to deal with the conceptus is attributed to the sophistication of the cytokine network regulated by leucocytes (Salamonsen et al., 2000). Stromal cells secrete cytokines such as IL-1 and IL-6 needed for the implantation of the blastocyst (Salamonsen et al., 2000). Eosinophils do not constitutively express P2X but human eosinophils were shown to do so when cultured with pro-inflammatory cytokines (Mohanty et al., 2001) and expression of $\mathrm{P} 2 \mathrm{X}_{7}$ receptors on eosinophils could be in itself an expression of activation. In accord with this hypothesis, we have observed that uterine cells are susceptible to extracellular ATP-induced permeabilization (a kind of fingerprint of $\mathrm{P}_{2} \mathrm{X}_{7}$ receptor functional expression) (Di Virgilio et al., 2001).

Similarly, in fibroblasts and macrophages ATP stimulation via activation of $\mathrm{P} 2 \mathrm{X}_{7}$ receptors promotes maturation and release of the pro-inflammatory cytokines IL-1 $\beta$ and IL-6 (Grahames et al., 1999; Solini et al., 1999). Although the exact role of the $\mathrm{P} 2 \mathrm{X}_{7}$ receptor on eosinophils, macrophages and fibroblasts in oestrus is not clear, it is reasonable to hypothesize that it plays an important role in uterine immune function by regulating ATP-mediated immune responses.

This study shows that the $\mathrm{P} 2 \mathrm{X}_{7}$ receptor is localised on eosinophils, macrophages and fibroblasts of the rat endometrium during oestrus. Some of the cells seem to undergo apoptosis, as revealed with $7 \mathrm{AAD}$ staining. $\mathrm{P} 2 \mathrm{X}_{7}$ receptor-positive cells have been observed in uterine tissue during oestrus at the electron microscopic level, allowing identification of positive cells by type. Findings suggest that the functions of eosinophils, as well as that of macrophages and fibroblasts, may be mediated through extracellular ATP acting via activation of the $\mathrm{P} 2 \mathrm{X}_{7}$ receptor. Further studies are required to determine the mechanism by which $\mathrm{P}_{2} \mathrm{X}_{7}$ receptors modulate the function of these cells in the uterus during oestrus. 


\section{Acknowledgements}

The authors are grateful to Dave Blundell and Tim Robson for their excellent technical support and to Dr. Chrystalla Orphanides for editorial assistance with the manuscript. This work was supported in part by funds from the Wellcome Trust. Dr. Coutinho-Silva is a Wellcome Trust fellow under number 062754/Z00Z and by funds from Conselho Nacional de Desenvolvimento Científíco e Technologico do Brasil (CNPq).

\section{References}

Abbracchio, M., Burnstock, G., 1998. Purinergic signalling: pathophysiological roles. Jpn. J. Pharmacol. 78, 113-145.

Atkinson, L., Milligan, C.J., Buckley, N.J., Deuchars, J., 2002. An ATP-gated ion channel at the cell nucleus. Nature 420, 42.

Bardini, M., Lee, Y.H., Burnstock, G., 2000. Distribution of P2X receptor subtypes in the rat female reproductive tract at late pro-oestrus/early oestrus. Cell Tissue Res. 299, 105-113.

Burnstock, G., 2001. Overview of P2 receptors: possible functions in immune cells. Drug Dev. Res. 53, 53-59.

Coutinho-Silva, R., Persechini, P.M., Bisaggio, R.D., Perfettini, J.L., Neto, A.C., Kanellopoulos, J.M., Motta-Ly, I., Dautry-Varsat, A., Ojcius, D.M., 1999. P2Z/P2X 7 receptor-dependent apoptosis of dendritic cells. Am. J. Physiol. 276, C1139-C1147.

Coutinho-Silva, R., Perfettini, J.L., Persechini, P.M., Dautry-Varsat, A., Ojcius, D.M., 2001. Modulation of $\mathrm{P} 2 \mathrm{Z} / \mathrm{P} 2 \mathrm{X}_{7}$ receptor activity in macrophages infected with Chlamydia psittaci. Am. J. Physiol. 280, C81C89.

Crowley, L.V., 1974. An Introduction to Clinical Embryology. Year Book Medical Publishers Inc., Chicago, p. 41.

Di Virgilio, F., 1995. The P2Z purinoreceptor: an intriguing role in immunity, inflammation and cell death. Immunol. Today 16, 524.

Di Virgilio, F., Chiozzi, P., Ferrari, D., Falzoni, S., Sanz, J.M., Morelli, A., Torboli, M., Bolognesi, G., Baricordi, O.R., 2001. Nucleotide receptors: an emerging family of regulatory molecules in blood cells. Blood 97, 587-600.

Dutton, J.L., Poronnik, P., Li, G.H., Holding, C.A., Worthington, R.A., Vandenberg, R.J., Cook, D.I., Barden,

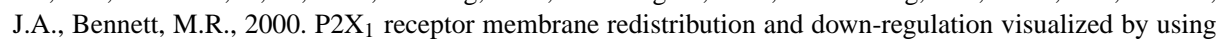
receptor-coupled green fluorescent protein chimeras. Neuropharmacology 39, 2054-2066.

Ennion, S.J., Evans, R.J., 2001. Agonist-stimulated internalisation of the ligand-gated ion channel P2X1 in the rat vas deferens. FEBS Lett. 489, 154-158.

Gordon, J.L., 1986. Extracellular ATP: effects, sources and fate. Biochem. J. 233, 309-319.

Gorodeski, G.I., Goldfarb, J., 1997. Extracellular ATP regulates transcervical permeability by modulating two distinct paracellular pathways. Am. J. Physiol. 272, C1602-C1610.

Grahames, C.B., Michel, A.D., Chessell, I.P., Humphrey, P.P., 1999. Pharmacological characterization of ATPand LPS-induced IL-1beta release in human monocytes. Br. J. Pharmacol. 127, 1915-1921.

Gröschel-Stewart, U., Bardini, M., Robson, T., Burnstock, G., 1999a. Localisation of P2X5 and P2X7 purinoceptors by immunohistochemistry in rat squamous epithelium. Cell Tissue Res. 296, 599-605.

Gröschel-Stewart, U., Bardini, M., Robson, T., Burnstock, G., 1999b. P2X receptors in the rat duodenal villus. Cell Tissue Res. 297, 111-117.

Hernandez, M.O., Neves, J.R.I., Sales, J.S., Carvalho, D.S., Sarno, E.N., Sampaio, E.P., 2003. Induction of apoptosis in monocytes by Mycobacterium leprae in vitro: a possible role for tumour necrosis factor- $\alpha$. Immunology $109,156-164$.

Lee, S.H., 1982. Uterine epithelial and eosinophil estrogen receptors in rats during the oestrus cycle. Histochemistry 74, 443-452.

Lee, H.Y., Bardini, M., Burnstock, G., 2000. Distribution of P2X receptors in the urinary bladder and the ureter of the rat. J. Urol. 163, 2002-2007. 
Li, G., Lee, E.M., Blair, D., Holding, C., Poronnik, P., Cook, D.I., Barden, J.A., Bennett, M.R., 2000. The distribution of $\mathrm{P} 2 \mathrm{X}$ receptor clusters on individual neurons in sympathetic ganglia and their redistribution on agonist activation. J. Biol. Chem. 275, 29107-29112.

Loesch, A., Burnstock, G., 2001. Immunoreactivity to $\mathrm{P}_{2} \mathrm{X}_{6}$ receptors in the rat hypothalamo-neurohypophysial system: an ultrastructural study with ExtrAvidin and colloidal gold-silver labelling. Neuroscience 106, 621-631.

Luque, E.H., Bassani, M.M., Ramos, J.G., Maffini, M., Canal, A., Kass, L., Caldini, E.G., Ferreira, J.M.C., Munoz de Toro, M.M., Montes, G.S., 1997. Leukocyte infiltration and collagenolysis in cervical tissue from intrapartum sheep. J. Vet. Med. A 44, 501-510.

McMaster, M.T., Newton, R.C., Dey, S.K., Andrews, G.K., 1992. Activation and distribution of inflammatory cells in the mouse uterus during the preimplantation period. J. Immunol. 148, 1699-1705.

Mohanty, G.J., Raible, G.D., McDermott, L.J., Pelleg, A., Schulman, E.S., 2001. Effects of purine and pyrimidine nucleotides on intracellular $\mathrm{Ca}^{2+}$ in human eosinophils: Activation of purinergic P2Y receptors. J. Allergy Clin. Immunol. 107, 849-855.

Oglesby, I.B., Lachnit, W.G., Burnstock, G., Ford, A.P.D.W., 1999. Subunit specificity of polyclonal antisera to the carboxy terminal region of $\mathrm{P} 2 \mathrm{X}$ receptors $\mathrm{P} 2 \mathrm{X}_{1}$ through $\mathrm{P}_{2} \mathrm{X}_{7}$. Drug Dev. Res. 47, 189-195.

Padykula, H.A., 1976. Cellular mechanisms involved in cyclic stroma renewal of the uterus. III. Cells of the immune response. Anat. Rec. 184, 49-71.

Padykula, H.A., Campbell, A.G., 1976. Cellular mechanisms involved in cyclic stromal renewal of the uterus. II. The albino rat. Anat. Rec. 184, 27-48.

Philpott, N.J., Turner, A.J.C., Scopes, J., Westby, M., Marsh, J.C.W., Gordon-Smith, E.C., Dalgleish, A.G., Gibson, F.M., 1996. The use of 7-amino actinomycin D in identifying apoptosis: simplicity of use and broad spectrum of application compared with other techniques. Blood 87, 2244-2251.

Ralevic, V., Burnstock, G., 1998. Receptors for purines and pyrimidines. Pharmacol. Rev. 50, 413-492.

Robertson, S.A., O'Connell, A.C., Hudson, S.N., Seamark, R.F., 2000. Granulocyte-macrophage colonystimulating factor (GM-CSF) targets myeloid leukocytes in the uterus during the post-mating inflammatory response in mice. J. Reprod. Immunol. 46, 131-154.

Ross, R., Klebanoff, S.J., 1966. The eosinophilic leukocyte fine structure studies of the changes in the uterus during the estrous cycle. J. Exp. Med. 124, 653-658.

Salamonsen, L.A., Dimitriadis, E., Robb, L., 2000. Cytokines in implantation. Semin. Reprod. Med. 18, 299-310.

Solini, A., Chiozzi, P., Morelli, A., Fellin, R., Di Virgilio, F., 1999. Human primary fibroblasts in vitro express a purinergic $\mathrm{P}_{2} \mathrm{X}_{7}$ receptor coupled to ion fluxes, microvesicle formation and IL-6 release. J. Cell Sci. 112, 297-305.

Tassell, W., Slater, M., Barden, J.A., Murphy, C.R., 2000. Endometrial cell death during early pregnancy in the rat. Histochem. J. 32, 373-379.

Wang, D., Ishimura, R., Walia, D.S., Muller, H., Dai, G., Hunt, J.S., Lee, N.A., Lee, J.J., Soares, M.J., 2000. Eosinophils are cellular targets of the novel uteroplacental heparin-binding cytokine decidual/trophoblast prolactin-related protein. J. Endocrinol. 167, 15-28.

Zarrow, M.X., Yochim, J.M., McCarthy, J.L., 1964. Experimental Endocrinology: A Sourcebook of Basic Techniques. Academic Press, New York, pp. 23-27. 